\title{
Rural Response to Increased Demand: Crop Choice in the Midwest, 1860-1880
}

\author{
Mary Eschelbach Gregson
}

\begin{abstract}
Demand for farm products grew, and the cost of marketing them shrank, between 1860 and 1880. The resulting commercialization of Midwestern agriculture has been widely discussed, but the production strategies that farmers pursued have not been adequately described or modeled. I find that an endowment-contingent model of crop choice provides a consistent explanation for farm production strategies at the micro-level on Missouri farms. The results call for a reexamination of the conventional wisdom that commercialization fostered specialization at the regional level.
\end{abstract}

$\mathbf{T}$ he population of the United States grew and urbanized between the Civil War and 1880, and the demand for food and other farm products increased. At the same time, Europe opened its markets to American farmers. The rural economy of the interior United States developed in response to these new sources of demand. With the rapid construction of trunk and feeder railroads after the Civil War, farmers in the Midwest-especially in the states west of the Mississippi Riverseized the opportunity to produce for wider markets.

Rising demand for farm produce and falling transportation and other marketing costs changed the production strategies of midwestern farmers in two ways. First, a smaller spread between farm-gate and market prices prompted farmers to sell a larger portion of their total output. Second, differential decreases in the price spread changed relative prices at the farm gate, which in turn altered the mix of commodities that farmers could profitably grow for sale. The first change is well known: farm surpluses were increasing and home manufactures were declining on most farms by the eve of the Civil War, and after the war, exports of commodities grew faster than total output. ${ }^{1}$ Farmers' strategies for commercialization, however, have been a neglected topic, even though many measures of farmers' performance depend on crop $\operatorname{mix}$.

The Journal of Economic History, Volume 53, No. 2 (June 1993). (c) The Economic History Association. All rights reserved. ISSN 0022-0507.

Mary Eschelbach Gregson is a graduate student of Economics at the University of Illinois at Urbana-Champaign, Champaign, IL, 61820.

For helpful comments and criticisms I thank Jeremy Atack, Lee Alston, Fred Bateman, Susan Carter, Sumner LaCroix, Jonathan Liebowitz, and the editors. For sharing his cartographic expertise, I thank Sean Hartnett. Data collection for my research was funded by the National Science Foundation (SES 91-00517).

${ }^{1}$ On self-sufficiency, see Tryon, Household Manufactures; and Atack and Bateman, To Their Own Soil, chap. 12. On markets and commercialization, see especially Danhof, Change in Agriculture, chap. 1. 
I model the crop mix decision as a function of farm-gate prices (market prices less marketing costs) and the farmer's agronomic endowment (proxied by soil diversity). That is, a farmer's decision to plant a given crop was influenced by increasing demand, falling transportation costs, and the suitability of his soil for the crop. Endowment-contingent production is a consistent explanation of farmers' crop mix strategies as they sold more of their output to meet the needs of distant consumers. The results of my analysis provide new insight into regional patterns of agricultural production during this important period in the development of the U.S. interior. Whereas agronomic endowments provided an opportunity for Wheat Belt farmers to concentrate on a limited number of crops as relative price changed, diverse soils provided some Corn Belt farmers the opportunity to increase the number of crops in their mix. Specialization was not a necessary consequence of commercialization.

\section{GROWING MARKETS AND CHANGING PRICES, 1860-1880}

The population of American cities grew 59 percent between 1860 and 1870 and 42 percent between 1870 and 1880 . Urban demand for foodstuffs grew at least as rapidly, and receipts of livestock and other commodities at seaboard cities increased steadily over the period 1869 to 1880 . In 1870 for example, 125,922 bushels of grain were received at northeastern ocean ports; in 1880 , receipts totaled 315,497 bushels. ${ }^{2}$ Much of the increase was consumed in the 939 (mostly northeastern) cities that were home to 28 percent of the American population in 1880 , but transatlantic trade absorbed a growing share after the Civil War. The volume of wheat exported from the U.S. grew by a factor of five from $1865 / 69$ to $1880 / 84$, and wheat and wheat flour exports from the North Central States grew from about $\$ 20$ million in 1870 to $\$ 127$ million in $1880 .^{3}$

Midwestern farmers were able to participate in the growing world wheat market because of improvements in ocean and overland transportation. Lower marketing costs were reflected in the convergence of international and regional prices of wheat during the postwar decades. The convergence of prices between major markets was paralleled by the convergence of farm-gate and market prices. But not all prices con-

\footnotetext{
${ }^{2}$ For data on urban population growth, see U.S. Department of Commerce, Historical Statistics, 1960, from Series A 181-209; and U.S. Department of Commerce, Census of Population: 1960, part A, table 8. Urban real wages were rising with population (Coelho and Shepherd, "Regional Differences"), and although demand for foodstuffs was income inelastic, quantity and quality of food demanded rose with income. Interregional trade data are from U.S. Secretary of the Treasury, First Annual Report, part 2, p. 111; U.S. Department of Agriculture, Report of the Commissioner, p. 284; and Hutchinson, "Regional Exports," p. 201.

${ }^{3}$ Exports are in constant 1913 dollars. Hutchinson, "Regional Exports," p. 140. For total wheat exports, see Harley, "Transportation," p. 227.
} 
verged at the same rate. For a Missouri farmer selling in the St. Louis market, the burden of marketing small grains fell faster than the burden of marketing livestock or feeds. Between 1867 and 1880, the burden of marketing oats and wheat in St. Louis fell at annual rates of 2 and $\mathbf{1 . 6}$ percent respectively. The burden of marketing corn and livestock fell as well, but at a rate of only 1 percent per year. ${ }^{4}$

Steady increases in northeastern and foreign demand for midwestern farm output, combined with differential decreases in marketing costs, turned relative prices at the farm gate in favor of small grains. The shift in relative farm-gate prices brought about changes in both regional and farm-level crop mixes between 1860 and 1880 . The extent of the changes in crop mix depended in turn on agronomic endowments.

\section{SOILS AND CROP CHOICE}

German rural economists, following the lead of J. H. von Thünen, were among the first to recognize that as transport costs fell, inherent soil suitability became more important in the crop mix decision. Theodor Brinkmann, in particular, emphasized that when marketing costs were low, the total cost of crop production depended on the natural conditions of the farm. As the constraints imposed by high transportation costs were ameliorated, the constraints imposed by nature became binding. ${ }^{5}$

Consider farmers A and B in Figure 1. Both operate farms in the Corn Belt. They are equidistant from the market and therefore face the same farm-gate prices. They could be neighbors. However, farmer A has little land suitable for small-grain production, whereas farmer B can grow good crops of small grain on more of his fields. Each field has a linear production possibilities curve (average yield is either 40 bushels of corn or 15 bushels of wheat on the first field, and 30 bushels of corn or 20 bushels of wheat on the second field, and so on); therefore at any relative price the farmer chooses to grow either feed or small grains in each field. ${ }^{6}$ Differences in soil diversity across the farm translate into a steeper overall production possibilities curve for farmer $A$ than for farmer $B$.

Given the production possibilities and the original farm-gate prices, neither farmer A nor farmer B produces significant quantities of small grains (Figure 2). When relative farm-gate prices shift in favor of small grains, both farmers grow more small grains. Furthermore, because

\footnotetext{
"See Harley, "Transportation"; and O'Rourke and Williamson, "Were Hecksher and Ohlin Right?" pp. 24-25. Missouri farm gate to St. Louis market price spreads were calculated from U.S. Department of Agriculture, "Prices"; and Merchants Exchange of St. Louis, Annual Statements.

s Brinkmann, Theodor Brinkmann's Economics, p. 152; see also Von Thünen, Von Thünen's Isolated State.

${ }^{6}$ Except of course if the ratio of prices equals the slope of the production possibilities curve for the field, in which case the outcome is indeterminate.
} 


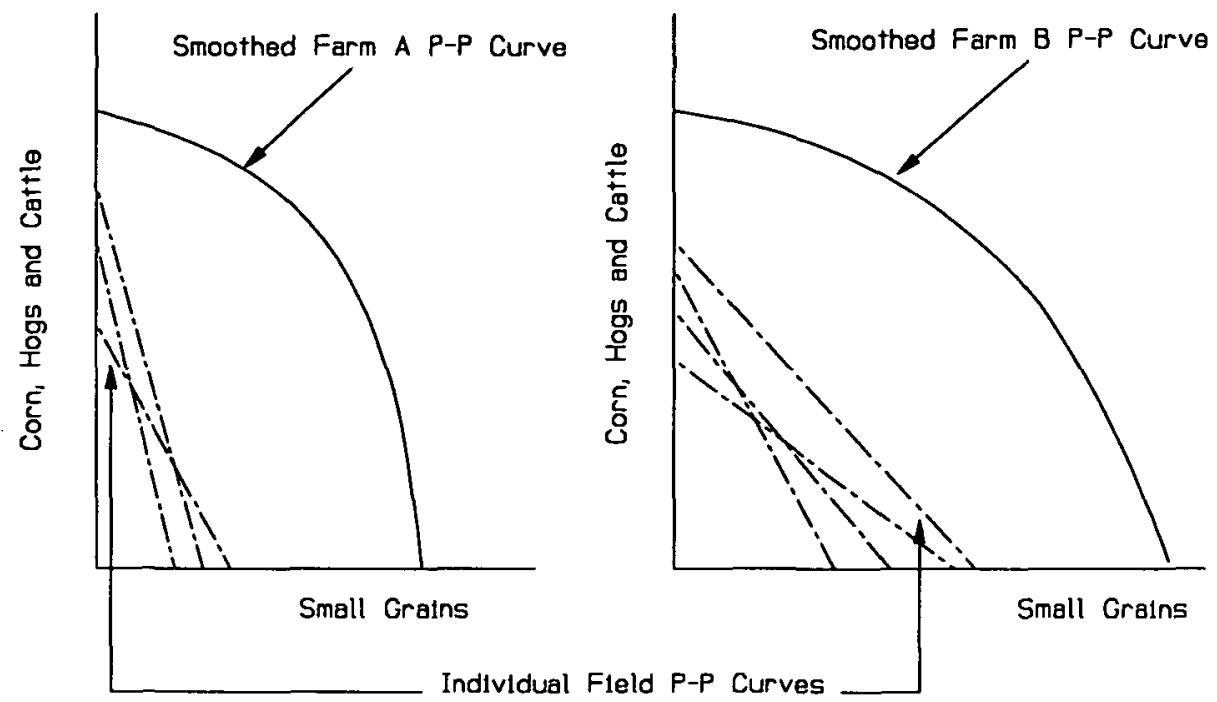

Figure 1

AGRONOMIC ENDOWMENTS AND FARM PRODUCTION POSSIBILITIES

Source: See text.

more diverse and/or suitable soils make small-grain production less costly for farmer $\mathrm{B}$, he adds more small grains to his crop mix than does farmer $\mathbf{A}^{7}$

\section{EVIDENCE FROM MISSOURI FARMS, 1860 AND 1880}

My farm-level evidence on crop choice is from a cluster sample of farms and households in six Missouri townships taken from the 1860 , 1870 , and 1880 manuscript censuses. The townships are geographically diverse and represent the range of Corn Belt and general farming practiced in Missouri and neighboring states. Regardless of the type of farming practiced, farmers in these six Missouri townships grew more small grains as relative prices changed. ${ }^{8}$

The increases in wheat production between 1860 and 1880 were

${ }^{7}$ The effect of agronomic endowments on crop choice can also be expressed algebraically in the farm profit function (see Gregson, "Strategies," chap. 8).

${ }^{8}$ Gregson, Census Sample. The six townships were originally part of the Bateman-Foust sample (see Bateman and Foust, "A Sample”). They are Rocky Fork (Boone County), Jackson (Camden County), Freeborn (Dunklin County), Prairie (Montgomery County), Salt River (Ralls County), and Mt. Pleasant (Scotland County). Farmers in the sample townships of Rocky Fork, Jackson, Prairie, Salt River Township, and Mt. Pleasant devoted substantial energy to grains and livestock. Prairie and Salt River townships comprise a subcategory within the com-livestock group where the feedlot system was in operation, albeit on a small scale. Farmers in Freeborn Township, in the "bootheel" of Missouri, grew cotton as a cash crop, but they still derived over 90 percent of their total gross farm income from noncotton crops. For more detail on the sample see Gregson, "Strategies," chap. 3. 


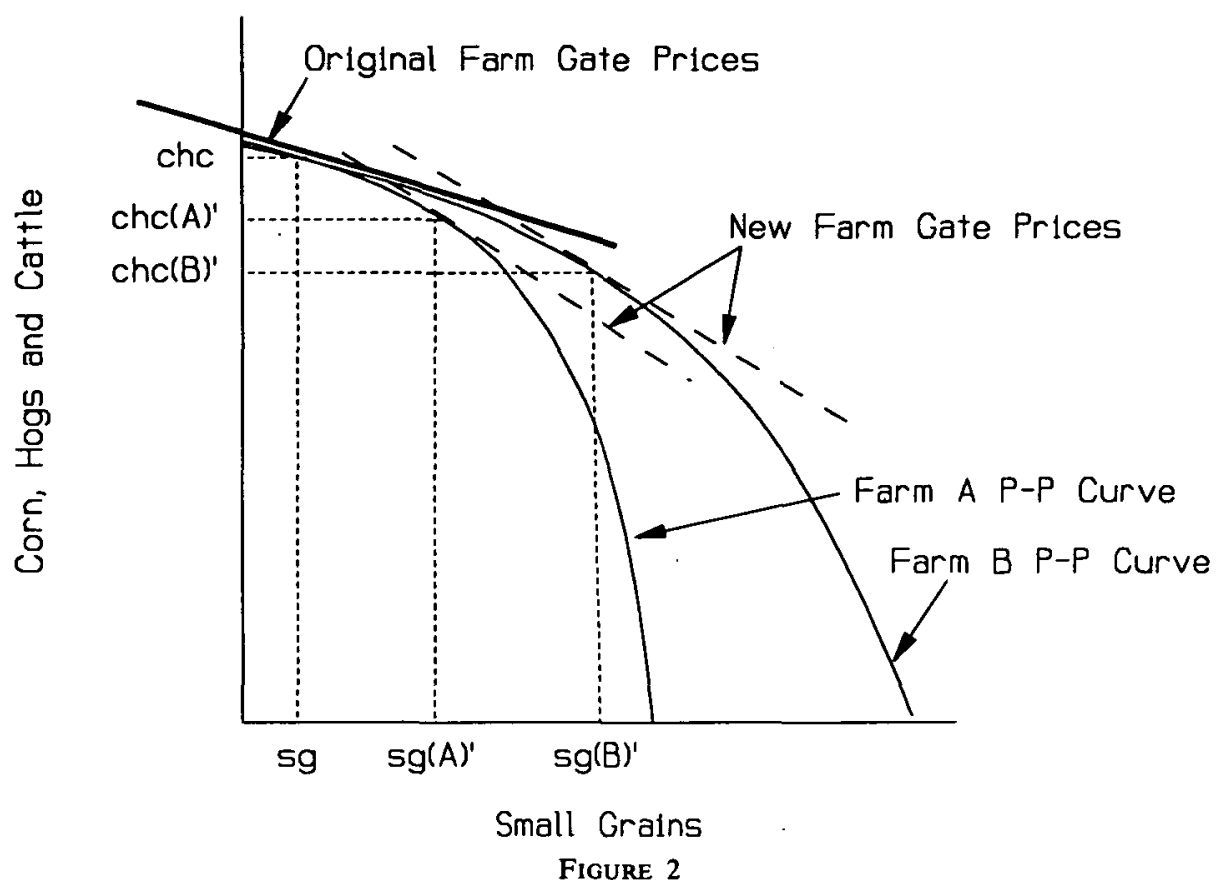

THE CROP MIX DECISION AND AGRONOMIC ENDOWMENTS

Source: See text.

dramatic-627 percent on average (Table 1). The smallest increase was 89 percent in Jackson Township; the largest, 5300 percent in Prairie Township. Production of other small grains increased as well. Together, wheat, oats, rye, barley, and buckwheat output grew an average of 769 percent on the Missouri farms. ${ }^{9}$ Not surprisingly, the share of small grains in gross farm income rose dramatically. In 1860 nearly all gross farm income came from livestock and feedgrain production. Wheat accounted for just one-twentieth of gross farm income from commodities traded interregionally. By 1880 , small grains generated one-fifth of gross farm income.

Table 1 also shows that differences in crop mix across farms were large. The distribution of small-grain output was not concentrated around the mean, but was wide: the standard deviation of bushels of small grains per acre on the farms was larger than the mean for the sample in all three census years. Although the average Missouri farmer grew more small grains, some farmers clearly pursued the strategy more vigorously. I sought to determine whether the farms in the upper tail of the distribution had more diverse agronomic endowments.

Unfortunately there is no precise geographic information about farms

\footnotetext{
9 The increase in oats cultivation cannot be explained by increased on-farm demand for oats due to the adoption of horsepowered machinery. Horses per farm in the sample declined from 4.2 in 1860 to 3.5 in 1880 .
} 
TABLE 1

OUTPUT AND INCOME FROM TRADED COMMODITIES ON FARMS IN MISSOURI TOWNSHIPS

\begin{tabular}{|c|c|c|c|c|c|c|c|}
\hline \multirow[b]{2}{*}{ Year } & \multirow{2}{*}{$\begin{array}{c}\text { Number } \\
\text { of } \\
\text { Farms }\end{array}$} & \multicolumn{3}{|c|}{ Wheat } & \multicolumn{3}{|c|}{ Small Grains } \\
\hline & & $\begin{array}{c}\text { Normalized } \\
\text { Bushels }\end{array}$ & $\begin{array}{l}\text { Standard } \\
\text { Deviation }\end{array}$ & $\begin{array}{c}\text { Gross } \\
\text { Income }(\%)\end{array}$ & $\begin{array}{c}\text { Normalized } \\
\text { Bushels }\end{array}$ & $\begin{array}{l}\text { Standard } \\
\text { Deviation }\end{array}$ & $\begin{array}{c}\text { Gross } \\
\text { Income }(\%)\end{array}$ \\
\hline 1860 & 900 & 0.09 & 0.247 & 3.7 & 0.24 & 0.995 & 5.9 \\
\hline 1870 & 1323 & 0.56 & 1.410 & 12.4 & 1.77 & 2.653 & 25.2 \\
\hline 1880 & 1663 & 0.65 & 1.164 & 13.0 & 2.10 & 2.660 & 21.3 \\
\hline $\begin{array}{l}\text { Change } \\
(1860-80 \text { as } \\
\% \text { of } 1860)\end{array}$ & & 627 & & 251 & 769 & & 261 \\
\hline
\end{tabular}

Notes: Bushels of output are normalized by size of farm: (bushels)/(total farm acreage). The denominator for the calculation of percentage of gross farm income derived from wheat and small grains is the value of crops traded interregionally: wheat, rye, corn, oats, barley, buckwheat, cotton (grown in Freeborn Township only), value added to cattle, and value added to hogs.

Sources: Quantities are from Gregson, Census Sample, farms in Missouri townships. Farm-gate prices of field crops for 1860 are from Atack and Bateman, To Their Own Soil, p. 222-23; for 1870 and 1880 they are from U.S. Department of Agriculture, "Prices," p. 138-39. For output prices missing from Atack and Bateman and USDA, "Prices," I substituted the price for the nearest state as given in other issues of the USDA Statistical Bulletin series on farm-gate prices (Bulletin Nos. 14, 15, and 17). When no farm-gate price was available in the USDA series, I substituted the national average price from Strauss and Bean, "Gross Farm Income." Detailed price and livestock value information is given in Gregson, "Strategies," chap. 5.

on the census manuscripts. I derived a simple but reliable measure of soil diversity for the owner-operated farms in 1860 and 1880 by linking the Salt River Township census records to the Ralls County tax rolls. The tax rolls provided the legal description of owned land from which digitized plats of Salt River Township were made. The plats were overlaid with a detailed soil survey map, and the number of distinct soil types on each farm was tabulated (Figure 3). I constructed this soil diversity variable for 78 farm owners in 1860 ( 75 percent of enumerated owners) and 156 owners in 1880 (78 percent). ${ }^{10}$

Table 2 shows the tabulation of the number of soils on individual farms in Salt River Township and the average bushels of small grains produced, normalized by farm size in acres. In general, the quantity of small grains produced increased with the number of soils found on the farm. The table also shows the one-way analyses of variance of small-grain output and number of soils on the farm. When soil diversity is the only source of variation considered, its effect on small-grains production is insignificant in 1860 , but very significant in 1880 . The results are consistent with my model of endowment-contingent crop

\footnotetext{
${ }^{10}$ Tax rolls of Ralls County for 1857 and 1879 were obtained with the assistance of the Ralls County Courthouse staff. The soil map is from Sweet and Watkins, Soil Survey. The digitization methodology was suggested and carried out by Sean Hartnett.
} 

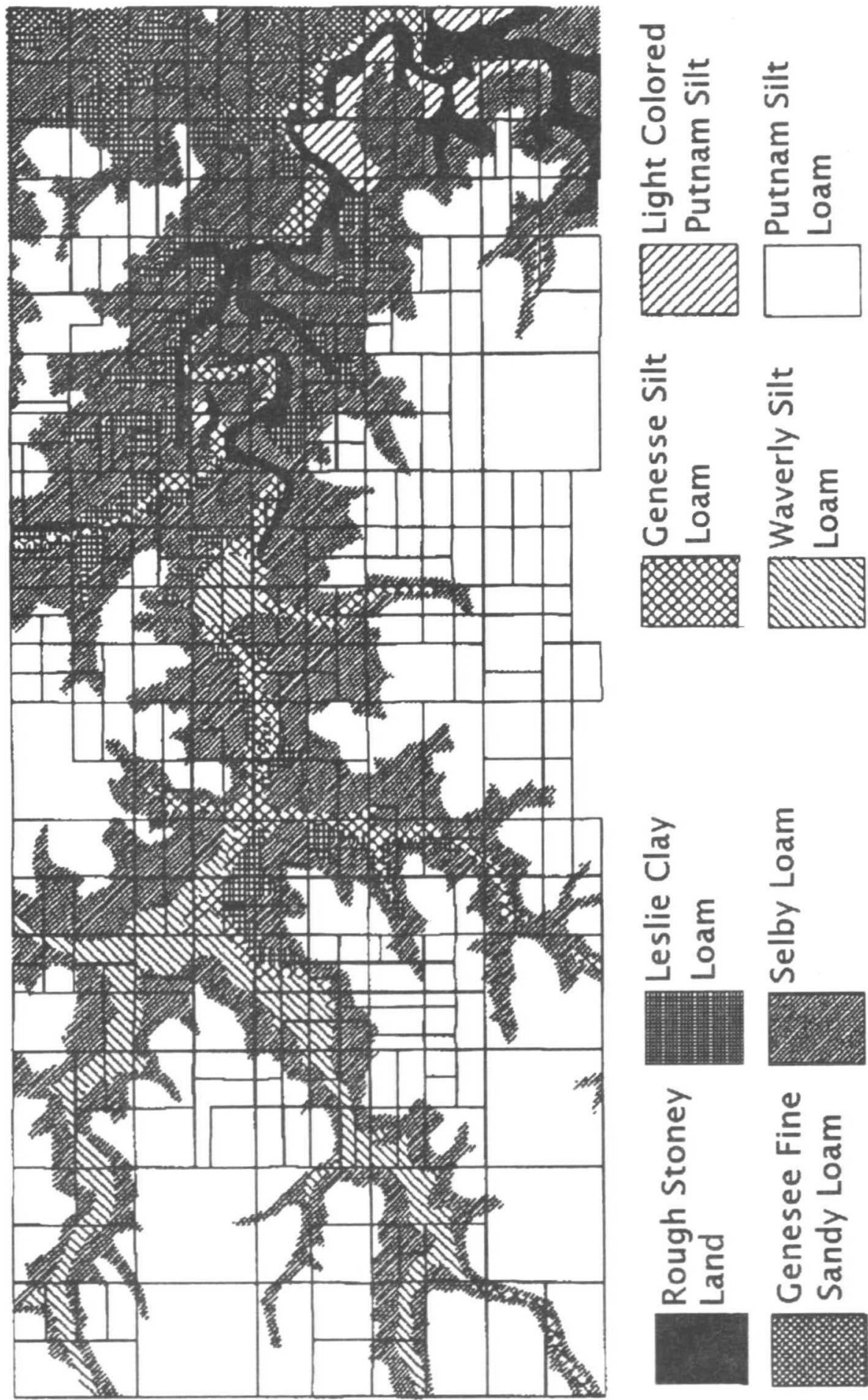

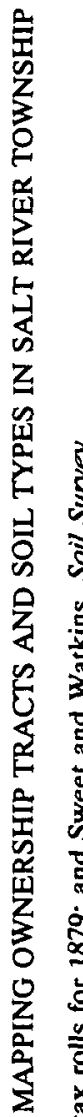

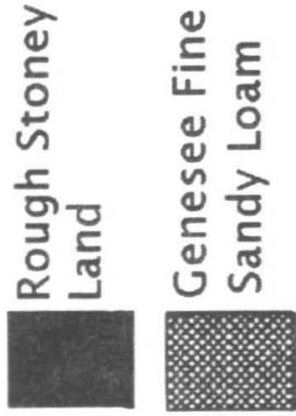

虽 
TABLE 2

HETEROGENEITY OF SOIL AND SMALL-GRAINS PRODUCTION

\begin{tabular}{|c|c|c|c|c|c|c|}
\hline \multirow{3}{*}{$\begin{array}{l}\text { Number of } \\
\text { Soils on } \\
\text { Farm }\end{array}$} & \multicolumn{6}{|c|}{ Bushels of Small Grains Produced, Normalized by Farm Size in Acres } \\
\hline & \multicolumn{3}{|c|}{1860} & \multicolumn{3}{|c|}{1880} \\
\hline & Mean & $\begin{array}{l}\text { Standard } \\
\text { Deviation }\end{array}$ & $N$ & Mean & $\begin{array}{l}\text { Standard } \\
\text { Deviation }\end{array}$ & $N$ \\
\hline 1 & 0.21 & 0.235 & 12 & 2.00 & 2.080 & 21 \\
\hline 2 & 0.24 & 0.397 & 13 & 1.97 & 1.754 & 50 \\
\hline 3 & 0.28 & 0.354 & 29 & 2.57 & 3.565 & 61 \\
\hline 4 or more & 0.33 & 0.351 & 24 & 2.04 & 2.437 & 27 \\
\hline All farms & 0.28 & 0.338 & 78 & 2.05 & 2.258 & 159 \\
\hline
\end{tabular}

One-Way ANOVA

Dependent Variable: Bushels of Small Grains Produced, Normalized by Farm Size in Acres

* = significant at the 5 percent level.

Sources: Gregson, Census Sample, farms in Salt River Township; Salt River Township tax rolls; and Sweet and Watkins, Soil Survey.

choice: only after demand increased and marketing costs decreased did farmers with heterogeneous soils grow more small grains.

Prices and agronomic endowments, however, were only two of the many elements that factored into farmers' production decisions. Table 3 shows the effects of the characteristics of the farm (the number of soils and farm size), the size of the farm labor force, attitudes toward risk (the dependency ratio), and human capital (farm owner-operator age, birthplace, and mobility), plus interactions, on small-grain production in 1860 and 1880. ${ }^{11}$ The model performs as expected. Endowment-contingent crop choice is again more consistent with the results for 1880 than with those for 1860 . In 1860, the characteristics of the farm's owner-

\footnotetext{
${ }^{11}$ Note that collinearity reduces the statistical significance of the independent variables in the saturated ANOVA models in Table 3. The description of the main and interaction effects of the variables on crop choice is based on the regressions underlying the ANOVA results. The ANOVA table is a more compact way of presenting the results because of the large number of categorical variables in the analysis.
} 
TABle 3

DETERMINANTS OF SMALL-GRAIN PRODUCTION ON FARMS, SALT RIVER TOWNSHIP, 1860 AND $1880^{\circ}$

\begin{tabular}{|c|c|c|c|c|c|c|c|c|}
\hline & \multicolumn{4}{|c|}{1860} & \multicolumn{4}{|c|}{1880} \\
\hline & $\begin{array}{l}\text { Partial } \\
\text { Sum of } \\
\text { Squares }\end{array}$ & $\begin{array}{c}\text { Degrees } \\
\text { of } \\
\text { Freedom }\end{array}$ & $\begin{array}{l}\text { Mean } \\
\text { Square }\end{array}$ & $F$-ratio & $\begin{array}{l}\text { Partial } \\
\text { Sum of } \\
\text { Squares }\end{array}$ & $\begin{array}{c}\text { Degrees } \\
\text { of } \\
\text { Freedom }\end{array}$ & $\begin{array}{c}\text { Mean } \\
\text { Square }\end{array}$ & $F$-ratio \\
\hline Model & 1.223 & 60 & .020 & 1.15 & 2.974 & 85 & .034 & $1.41^{* *}$ \\
\hline \multicolumn{9}{|l|}{ Main effects: } \\
\hline No. of Soils & .085 & 4 & .021 & 1.20 & .175 & 5 & .035 & 1.42 \\
\hline Farm Size & .115 & 5 & .023 & 1.31 & .107 & 6 & .017 & 0.72 \\
\hline Labor & .045 & 1 & .045 & $2.55^{*}$ & .052 & 1 & .052 & $2.10^{*}$ \\
\hline Dependency Ratio $^{b}$ & .037 & 1 & .037 & $2.11^{*}$ & .007 & 1 & .007 & 0.30 \\
\hline Age $^{\mathrm{b}}$ & .023 & 2 & .011 & 0.67 & .012 & 2 & .006 & 0.26 \\
\hline Birthplace & .048 & 4 & .012 & 0.68 & .025 & 4 & .006 & 0.26 \\
\hline Mobility & .001 & 1 & .000 & 0.02 & .019 & 1 & .019 & 0.80 \\
\hline \multicolumn{9}{|l|}{ Interaction effects: } \\
\hline Soils $\cdot$ Farm Size & .232 & 12 & .019 & 1.09 & .652 & 19 & .034 & $1.39^{*}$ \\
\hline Soils $\cdot$ Labor & .098 & 4 & .024 & 1.39 & .103 & 4 & .025 & 1.05 \\
\hline Soils $\cdot$ Dependency Ratio & .022 & 3 & .007 & 0.43 & .026 & 3 & .008 & 0.35 \\
\hline Soils $\cdot$ Age & .177 & 7 & .025 & 1.43 & .073 & 6 & .012 & 0.50 \\
\hline Soils $\cdot$ Birthplace & .095 & 4 & .023 & 1.35 & .064 & 9 & .007 & 0.29 \\
\hline Soils $\cdot$ Mobility & .027 & 2 & .013 & 0.77 & .171 & 3 & .057 & $2.31^{* *}$ \\
\hline Farm Size $\cdot$ Age & .196 & 6 & .032 & $1.85^{*}$ & .261 & 12 & .021 & 0.88 \\
\hline Age $\cdot$ Dependency Ratio & .029 & 2 & .014 & 0.84 & .201 & 7 & .028 & 1.16 \\
\hline Residual & .300 & 17 & .017 & & 1.733 & 70 & .024 & \\
\hline Total & 1.523 & 77 & .019 & & 4.707 & 155 & .030 & \\
\hline$N$ & 78 & & & & 156 & & & \\
\hline $\begin{array}{l}\text { Root mean square } \\
\text { error }\end{array}$ & .133 & & & & .157 & & & \\
\hline$R$-square & .80 & & & & .63 & & & \\
\hline Adjusted $R$-square & .11 & & & & .18 & & & \\
\hline
\end{tabular}

* = significant at the 15 percent level.

** = significant at the 10 percent level.

- Saturated ANOVA model. No additional interactions added to the significance of the model.

bontinuous, rather than categorical, variables.

Notes: The dependent variable is bushels of small grains produced, normalized by size of farm in acres. Number of soils is the number of soil types found on land owned by the farmer. Categories of farm size are 3-20 total acres in the census operational unit, 21-40 acres, 81-160 acres, 161-320 acres, and over 320 acres. Farm size is also a proxy for wealth. Labor is the potential male labor force in the household of the owner-operator. Males over 14 are assumed to have a labor participation rate of 1 , males 11-14 are assumed to have a labor participation rate of 0.17 . The dependency ratio is a proxy for risk aversion and is defined as the number of children ten years and younger divided by the number of adults and teens over ten residing in the farm operator's household as reported on the census schedules. Categories of the owner-operator's age are 14-30 years, 31-50 years, and over 50 years. Categories of owner-operator's birthplace are born in Missouri, the Midwest (excluding Missouri), Northeast, South, and Foreign-born. For the 1860 regression, the mobility variable equals one if the owner-operator was born in Missouri, and zero otherwise. For the 1880 regression mobility equals one if the owner-operator was linked backward to the 1870 manuscript census, and zero otherwise. Age, birthplace, and mobility are used as measures of human capital.

Sources: Gregson, Census Sample, farms in Salt River Township, Salt River Township tax rolls, and Sweet and Watkins, Soil Survey. Labor participation rates are from Lebergott, "Labor Force," and Fogel and Engerman, "Relative Efficiency." 
operator and his household contributed more to the crop mix decision than did the characteristics of the farm, including soil variability. By contrast, in 1880 the interaction of soil variability with farm size and mobility were important determinants of crop choice.

Because a field was not usually planted in multiple crops simultaneously, small farms were at a disadvantage for adding crops to the mix. Yet after controlling for soil variability and assuming yield did not depend on farm size, larger farms did not devote a larger proportion of their land to small grains than smaller farms in 1860. If "lumpiness" in the land input prevented small farmers from adding small grains to their crop mixes, the interaction between number of soils and farm size would be strong. It was not in 1860 . In 1880, however, small farms appeared less divisible, perhaps because of mechanization. Large farms with heterogeneous soils were likely to produce relatively more small grains than small farms with equally varied soils in $\mathbf{1 8 8 0}$.

The constraints that labor availability placed on crop choice in $\mathbf{1 8 6 0}$ and 1880 have a more complicated interpretation. There were two periods of peak labor demand on midwestern farms: cultivation of young corn plants and harvest of small grains. The labor available in the farm household was an effective cap on small-grain production because harvesting was labor-intensive, had to be performed in a short span of time, and because casual hired labor was scarce. ${ }^{12}$ In 1860 and 1880 , the main effect of a larger household labor force was to ensure adequate labor for corn cultivation. Table 3 shows that larger quantities of household labor were associated with crop mixes that were less concentrated on small grains and more concentrated on corn, hogs and cattle. On the other hand, the interaction between soils and the farm labor force has a positive (but not statistically significant) effect on small-grain production. Thus, farmers with diverse soils required a larger on-farm labor force to harvest grains, but farmers with homogeneous soils used their labor in the corn fields.

Increased cultivation of small grains coincided with increased participation in wider, riskier markets. Thus, more risk-averse farmers might have acted conservatively and might have preferred the traditional corn, hogs, and cattle crop mix. I used two proxies for risk aversion: the ratio of dependents ten years of age and under to adults in the farm household and farm wealth as indicated by size of farm. Again, the effect of farm size on small-grain production was negligible. The effect of the composition of the farm household was strong in 1860 but weak in 1880 . Insuring the family against disaster may have been a consideration in the earlier year but was outweighed by the benefits of growing small grains for sale by 1880 .

\footnotetext{
12 "Hired hands were scarce and high priced when available. Farmers depending upon casual wage labor lived in fear that workers, when needed, might not be available at any price that justified their hire." Atack and Bateman, To Their Own Soil, p. 186.
} 
The farmer's ability to exploit soil variations on his farm profitably depended upon his knowledge of soils, crop varieties, and cultivation methods. I estimated the human capital of farmers using age as a measurement of experience and birthplace and mobility as measurements of familiarity with specific conditions. Birthplace had no effect on crop choice after I controlled for soil variability. The interaction between age and farm size, however, had a positive effect on small-grain production in 1860: farmers with more experience and more acres grew more small grains. Thus, human capital played a role in crop choice in 1860 , regardless of soil variability.

In 1880 , the role of human capital in crop choice was different. Raw experience (age) was no longer important. Long-term residence mattered. Farmers who had lived in Salt River Township for at least ten years (that is, they were linked from the 1880 census manuscript back to the 1870 manuscript) grew more small grains if they had diverse soils and relied on corn and livestock if they had homogeneous soils. Although there were differences between the crop mixes of in-migrants with diverse soils and in-migrants with homogeneous soils, those differences were not as large as for long-term residents. Experience with local soils seems to have provided farmers with important information about the relative profitability of small grains.

When transport costs were high, crop choice was mainly a function of distance from the market. Variation in agronomic endowments did not result in variation in crop mixes. But soil type became an important factor in crop choice after the demand increases and marketing cost decreases of the post-Civil War period. Farmers who had varied soils and the knowledge to exploit them responded to the changes in relative prices by growing more small grains than farmers with less knowledge about the specific conditions in Salt River Township.

\section{REGIONAL SPECIALIZATION REVISITED}

The shift by Missouri farmers from a crop mix strategy almost wholly devoted to corn and livestock in 1860 to a strategy that included substantial amounts of small grains in $\mathbf{1 8 8 0}$ seems to run counter to the conventional story of regional specialization in agriculture during the last half of the nineteenth century. ${ }^{13}$ As marketing costs fell and demand rose, the story goes, farmers on the Plains became the nation's producers of wheat, farmers in the Northeast produced perishables, farmers in the South strengthened their ties to cotton, and farmers in the Midwest came to produce an overwhelming share of U.S. feedgrains and finished livestock. Agricultural historians call this regional specialization. But specialization has another definition: the concentration of

\footnotetext{
${ }^{13}$ A typical description of an ever more specialized agriculture can be found in Walton and Rockoff, History, p. 303. Also see Winters, "Economics," pp. 83-84.
} 


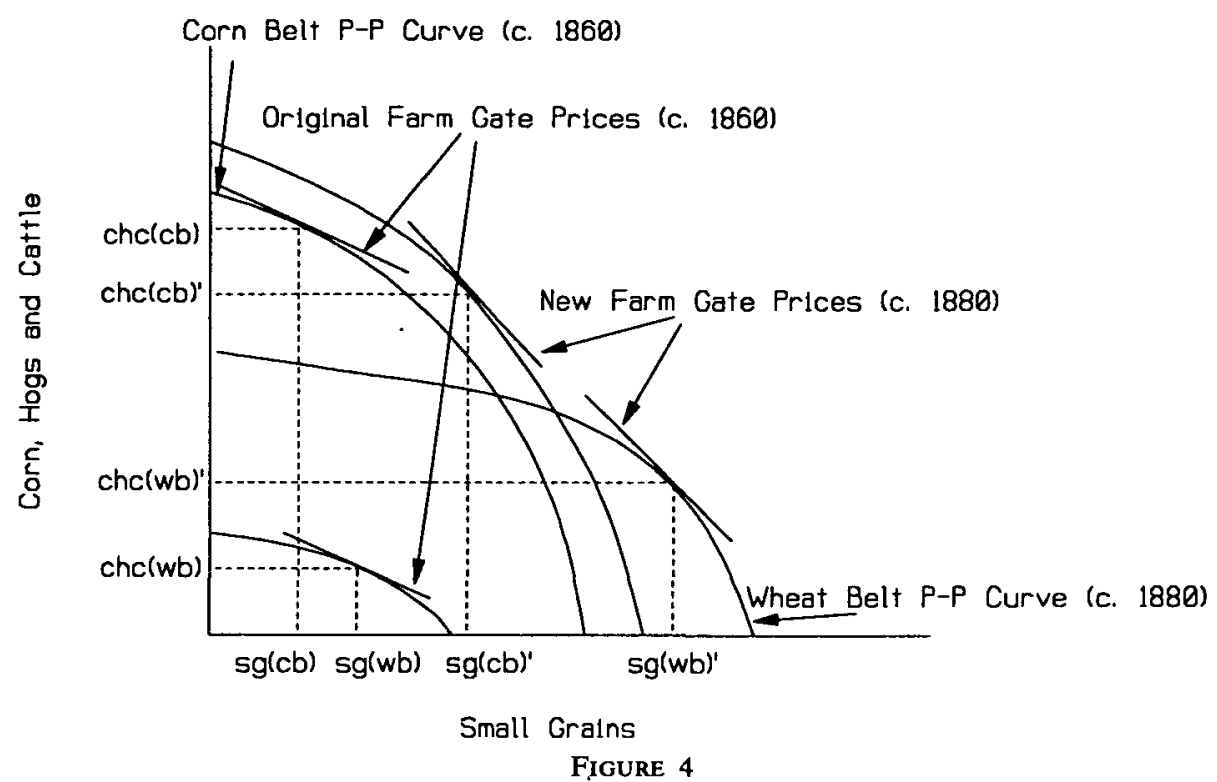

AGRONOMIC ENDOWMENTS AND CROP CHOICE AT THE REGIONAL LEVEL Source: See text.

farm production on fewer and fewer outputs. ${ }^{14}$ Using the endowmentcontingent model of crop choice, it is easy to show that the first definition does not imply the second. Though farmers in the Corn Belt were the primary corn, hogs, and cattle producers for the nation during the period, they expanded their output of other small grains as well.

Figure 4 shows the dynamic of the endowment-contingent model for two regions. The regional crop mix outcome is analogous to the farm-level outcome of Figure 2. The regions are equidistant from the market but have different soils and climates. The production possibilities curve for the Corn Belt region indicates that although the cultivation of small grains (SG) is possible, it requires a large sacrifice of corn, hog, and cattle production (CHC). Similarly, while the Wheat Belt can produce both small grains and livestock-feedgrains, its production of small grains falls off dramatically with each increase in livestockfeedgrain production. Thus for any nonzero price, Corn Belt farmers produce more livestock and feedgrains than Wheat Belt farmers who, in turn, produce relatively more small grains. This was the situation under the "original prices at the farm gate" of Figure 4.

Extensive growth in the regions would not have changed the composition of the crop mixes, other things equal. But in response to the relative price shift caused by higher demand and lower transport costs,

\footnotetext{
${ }^{14}$ Shares of national agricultural output by region can be computed from the state aggregates found in the U.S. Census Office, Compendium of the Tenth Census, table 43. For a historiography of agricultural specialization see Gregson, "Specialization."
} 
Wheat Belt farmers clearly specialized. They devoted more of their resources to their mainstay, small-grains production. Corn Belt farmers also found it advantageous to grow more small grains. But this meant that Corn Belt crop mix became more diversified in an absolute sense.

\section{CONCLUSION}

Understanding crop choice is necessary for understanding how American farmers adjusted to their changing economic environment, especially during the late nineteenth century when industry finally overtook agriculture as the leading sector in terms of value added. William Parker has identified transport costs, movements of labor and capital, and differences in the natural suitability of land for various crops as the three elements that determined the pattern of agricultural production. I have highlighted the role of agronomic endowments in the analysis of crop choice by Missouri farmers, and I have shown how explicit incorporation of soil endowments and climate affects regional analysis. Only additional studies of farm-level decisions can lead to a clearer picture of how choices by individual farmers shaped regional aggregates. As Parker warned, "[ $t]$ he exact effects of each of these influences have never been sorted out, and the economic history of regional specialization needs closer scrutiny." 15

${ }^{15}$ Parker, "Agriculture," p. 377.

\section{REFERENCES}

Atack, Jeremy, and Fred Bateman, To Their Own Soil: Agriculture in the Antebellum North (Ames, IA, 1987).

Bateman, Fred, and James D. Foust, "A Sample of Rural Households Selected from the 1860 Manuscript Censuses," Agricultural History, 48 (Jan. 1974), pp. 75-93.

Brinkmann, Theodor, Theodor Brinkmann's Economics of the Farm Business, trans. M. R. Benedict (Berkeley, CA, 1935).

Coelho, Philip R. P., and James F. Shepherd, "Regional Differences in Real Wages: The United States, 1851-1880," Explorations in Economic History, 13 (July 1976), pp. 203-30.

Danhof, Clarence, Change in Agriculture: The Northern United States 1820-1870 (Cambridge, MA, 1969).

Fogel, Robert, and Stanley Engerman, "The Relative Efficiency of Slavery: A Comparison of Northern and Southern Agriculture in 1860," Explorations in Economic History, 8 (Spring 1971), pp. 353-67.

Gregson, Mary Eschelbach, Census Sample of Six Missouri Townships. These data are available through the Inter-University Consortium for Political and Social Research, Ann Arbor, MI.

Gregson, Mary Eschelbach, "Strategies for Commercialization: Missouri Agriculture 1860-1880" (Ph.D. diss., University of Illinois, 1993). 
Gregson, Mary Eschelbach, "Specialization in Late Nineteenth Century Midwestern Agriculture: Missouri as a Test Case," Agricultural History, 67 (Winter 1993), pp. 16-35.

Harley, C. Knick, "Transportation, the World Wheat Trade, and the Kuznets Cycle, 1850-1913," Explorations in Economic History, 17 (July 1980), pp. 218-50.

Hutchinson, William K., "Regional Exports to Foreign Countries: United States, 1870-1914,' in Paul Uselding, ed., Research in Economic History (Greenwich, CT, 1982), vol. 7, pp. 133-238.

Lebergott, Stanley, "Labor Force and Employment, 1800-1960," in Conference on Research in Income and Wealth, Output, Employment and Productivity in the United States After 1800, Studies in Income and Wealth 30 (Princeton, NJ, 1966), pp. 177-204.

Merchants Exchange of St. Louis, Annual Statement of the Trade and Commerce of St. Louis (St. Louis, various years).

O'Rourke, Kevin, and Jeffrey Williamson, "Were Heckscher and Ohlin Right? Putting the Factor-Price Equalization Theorem Back Into History," NBER Working Paper Series on Historical Factors in Long Run Growth, No. 37 (1992).

Parker, William, "Agriculture," in Lance Davis et al., American Economic Growth (New York, 1972), pp. 369-417.

Salt River Township Tax Rolls, 1857 and 1879 volumes, Ralls County Courthouse, New London, MO.

Strauss, F., and L. H. Bean, "Gross Farm Income and Indices of Farm Production and Prices in the United States 1869-1937," USDA Technical Bulletin 703 (Washington, DC, 1940).

Sweet, A. T., and W. I. Watkins, Soil Survey of Ralls County Missouri (Washington, DC, 1914).

Tryon, Rolla M., Household Manufacturers in the United States, 1640-1860 (Chicago, 1917).

U.S. Census Office, Compendium of the Tenth Census (Washington, DC, 1883).

U.S. Department of Agriculture, "Prices of Farm Products Received by Producers: The North Central States," Statistical Bulletin 15 (Washington, DC, 1927).

U.S. Department of Agriculture, Report of the Commissioner of Agriculture (Washington, DC, 1883).

U.S. Department of Agriculture, Statistical Bulletin (various issues).

U.S. Department of Commerce, Bureau of the Census, Census of Population: 1960, Vol. I, Characteristics of the Population (Washington, DC, 1961).

U.S. Department of Commerce, Bureau of the Census, Historical Statistics of the United States: Colonial Times to 1970 (Washington, DC, 1975).

U.S. Secretary of the Treasury, First Annual Report on the Internal Commerce of the United States, Part 2 (Washington, DC, 1877).

Von Thünen, J. H., Von Thünen's Isolated State, ed. and trans. Carla M. Wartenburg (Oxford, 1966).

Walton, Gary, and Hugh Rockoff, History of the American Economy (6th edn., San Diego, CA, 1990).

Winters, Donald, "The Economics of Midwestern Agriculture, 1865-1900," in Lou Ferleger, ed., Agriculture and National Development (Ames, IA, 1990), pp. 75-95. 